\title{
STRUCTURAL DIVERSITY OF LOG OF Eucalyptus spp. GENOTYPES.
}

\author{
Olívia Pereira Lopes ${ }^{1}$; Jonnys Paz Castro²; Tatiana Paula Marques de Arruda3 $;$ João Vicente de Figueiredo \\ Latorraca $^{4}$; Fábio Akira Mori ${ }^{5}$ \\ 1 * Federal University of Uberlândia, Institute of Agrarian Sciences, Monte Carmelo, Minas Gerais, Brazil - olivia.plopes@hotmail \\ ${ }^{2}$ Federal Rural University of Rio de Janeiro, Department of Forest Products, Seropédica, Rio de Janeiro, Brazil - jonnys_33@hotmail.com \\ ${ }^{3}$ State University of Mato Grosso, Department of Forest Engineering, Alta Floresta, Mato Grosso, Brazil - tatianarruda@unemat.br \\ ${ }^{42}$ Rural Federal University of Rio de Janeiro, Department of Forest Products, Seropédica, Rio de Janeiro, Brazil - jonnys_33@hotmail.com \\ ${ }^{5}$ Federal University of Lavras, Department of Forestry Sciences, Lavras, Minas Gerais, Brazil - mori@dcf.ufla.br
}

Recebido para publicação: 28/01/2018 - Aceito para publicação: 26/09/2018

\begin{abstract}
Anatomical studies, besides being useful in the identification of the species, make it possible to generate information about the structure of the $\log$ in order to identify the relationships between the $\log$ and the technological properties of the wood. The aim of this work was to anatomically characterize the log of different genotypes of the genus Eucalyptus planted in the state of Minas Gerais - Brazil and to describe its main differences and/or similarities. Three genetically improved genotypes were evaluated, Eucalyptus urophylla $\mathrm{x}$ Eucalyptus grandis; Eucalyptus urophylla and Eucalyptus urophylla $\mathrm{x}$ Eucalyptus camaldulensis, aged whithin 6 to 7 years old. Discs of 9 trees were removed at breast height (1.30 meters from the ground). From each disk, specimens were obtained in the medulla-cambial direction with dimensions of approximately $2 \mathrm{~cm}^{3}$ to make permanent sheets, being that the anatomical characterization of the genotypes followed the recommendations of the IAWA Committee (1989). The results showed that the genotypes of Eucalyptus are very similar, however, differences were observed in the axial parenchyma and in the composition of rays.

Keywords: Clones, anatomy, secondary xylem.
\end{abstract}

\section{Resumo}

Diversidade estrutural do lenho de genótipos de Eucalyptus spp. Estudos anatômicos são importantes para a identificação de espécies, estrutura anatômica relacional e propriedades tecnológicas do xilema secundário. Esse estudo objetiva caracterizar genótipos de Eucalyptus plantados no estado de Minas Gerais e descrever suas principais diferenças. Três genótipos foram caracterizados, Eucalyptus urophylla x Eucalyptus grandis; Eucalyptus urophylla e Eucalyptus urophylla x Eucalyptus camaldulensis, com idades entre 6 e 7 anos. Foram obtidos discos a partir de 9 árvores na altura do peito (1,30 metros do solo). Amostras com $2 \mathrm{~cm}^{3}$ foram obtidas em cada disco da medula-Câmbio para confeccionar lâminas permanentes, sendo que a caracterização anatômica de genótipos seguiu as recomendações da IAWA Committee (1989). Os genótipos da anatomia da madeira de Eucalyptus são muito similares, contudo, diferenças são observadas no parênquima axial e na composição de raio entre os genótipos.

Palavras-chave Clones, anatomia, xilema secundário.

\section{INTRODUCTION}

The anatomical studies, besides the identification of the species, make it possible to generate information about the wood structure, allowing to identify its interrelationship with the technological characteristics of the wood. Studies on the anatomy of the species of the genus Eucalyptus mainly address the fiber dimensions, which present great potential for use as raw material in the forest industry.

The genus Eucalyptus belongs to the family Myrtaceae and has more than 600 species, they develop in diverse conditions of soil and climate. It has great economic importance in the country, since it constitutes a large part of the plantations of the forest sector (RAPASSI et al., 2008). The species of this genus are widely planted in Brazil due to the rapid growth and quality of the wood, for the production of cellulose, fibre panels, firewood, charcoal and civil construction (DIAS JÚNIOR et al., 2016). Some species of the genus Eucalyptus are well studied, but there are other species of this genus in which the studies are scarcer, as well as for several hybrids (PIRRALHO et al., 2014; PRINSEN et al. 2012).

By characterizing the anatomical structure of the log, determining the dimensions of its cells and its structural variations, it is possible to predict the technological behavior of the material that is fundamental to the companies that consume this raw material. A growth in pulp production of around 13 million tons per year of Eucalyptus wood was expected in the year of 2015 in Brazil, due to the growth and creation of cellulose and paper 
industries in the country. With this, there is necessity of improvements in the productivity and quality of the clonal forests of Eucalyptus (ALVES et al., 2011).

Despite the great potential of species of the genus, there are specific restrictions of each species, however, these are minimized or solved with the implementation of genetic improvement programs, seeking the production of raw material of quality with characteristics appropriated to the processes and products, as well as cost reduction and production time. Brisola and Demarco (2011) observed gains in anatomical characteristics relevant to the forest industry for hybrids of Eucalyptus, making their use faster and the cost of the final product lower.

The anatomical study of different species, as well as the variation among individuals of the same species, is an important tool for decision making in the forest sector, such as genetic improvement, forestry and forest management (BALDIN et al., 2017).

Currently, due to the gaps that have arisen over time and the improvement of the genus species, directly influencing the $\log$ structure, there is a need to anatomically study the genotypes of the genus Eucalyptus. Only a constant effort can result in a greater understanding of the anatomy of wood and its evolution. The need for such an effort is better understood when there is a group with a diversity of wood-producing species and there is difficulty in distinguishing them (CARLQUIST, 2010). Thus, it is fundamental to verify the anatomical differences of the existing species within this genus so that it is possible to make a distinction between them and infer about the anatomical characteristics more favorable to the productivity and quality of the raw material for the production of cellulose pulp, paper and charcoal.

With that, the objective of this work was to describe the log of the different genotypes of the genus Eucalyptus, in order to allow the differentiation of the genotypes of this genus so homogeneous, using the anatomy of wood as a tool.

\section{MATERIAL AND METHODS}

\section{Collection and sampling area}

The work was developed using wood from plantations from three companies that commercialize genotypes of the genus Eucalyptus L'Hérit, located in the state of Minas Gerais. Three trees of each genotype most used by each company, with commercial age (Table 1), were collected.

Table 1. Local data and dendrometric (average) data of the genotypes collected.

Tabela 1. Dados do local e dendrométricos (médios) dos genótipos coletados

\begin{tabular}{|c|c|c|c|c|c|c|}
\hline Genotype & Source & Coordinates & $\begin{array}{c}\text { Planting } \\
\text { Soil }\end{array}$ & $\begin{array}{c}\text { Age } \\
\text { (years) }\end{array}$ & $\begin{array}{c}\text { DBH * } \\
(\mathbf{c m})\end{array}$ & $\begin{array}{c}\text { HM * } \\
(\mathbf{m})\end{array}$ \\
\hline $\begin{array}{l}\text { E. urophylla } \times E . \\
\text { grandis }\end{array}$ & Belo Oriente & $\begin{array}{l}\mathrm{S}^{*} 19^{\circ} 13^{\prime} 04^{\prime \prime} \\
\mathrm{W}^{*} 49^{\circ} 27^{\prime} 26^{\prime \prime}\end{array}$ & $\begin{array}{l}\text { LAd1 } \\
\text { LAw1 }\end{array}$ & 6.6 & 14.65 & 23.5 \\
\hline Eucalyptus urophylla & Curvelo / Paraopeba & $\begin{array}{l}\text { S } 18^{\circ} 44^{\prime} 57^{\prime \prime} \\
\text { W } 44^{\circ} 26^{\prime} 48^{\prime \prime}\end{array}$ & LAVd1 & 7 & 15.62 & 26.28 \\
\hline $\begin{array}{l}\text { E. urophylla } \mathrm{x} \text { E. } \\
\text { camaldulensis }\end{array}$ & Paraopeba & $\begin{array}{c}\text { S } 19^{\circ} 16^{\prime} 54^{\prime \prime} \\
\text { W } 44^{\circ} 24^{\prime} 32^{\prime \prime}\end{array}$ & $\mathrm{NF}^{*}$ & 7 & 15.4 & 21.92 \\
\hline
\end{tabular}

*DBH: Diameter at breast height; HM: mean height; S: South latitude; W: West longitude; NF: not supplied

From each tree was obtained a disc approximately five centimeters thick at the breast height $(1.30 \mathrm{~m}$ from the ground). Three specimens were prepared, one near the medulla, one in the intermediate region and one near the cambium, with dimensions of $2 \times 2 \times 2 \mathrm{~cm}$ (tangential, radial and longitudinal) of the diametrical section of the sampled discs.

\section{Microscopic description}

For the anatomical characterization of the genotypes, permanent histological sheets were made. After cooking in water, samples of approximately $2 \mathrm{~cm}^{3}$ were sectioned in the transverse, tangential and radial planes by approximately $12 \mu \mathrm{m}$. The histological sections were clarified, stained, dehydrated in a gradual alcoholic battery of $30 \%$ to $100 \%$ and the blades were permanently mounted on Entelan ${ }^{\circledR}$ synthetic resin.

Measurements and descriptions were made according to the list of microscopic characteristics for angiosperms of the IAWA Committee (1989). The dimensions of these anatomical elements were obtained in an image analysis equipment, Olympus BX41 microscope with coupled camera, using the image analysis software.

In order to analyze the intervascular pits in scanning electron microscopy, it was necessary to reduce the sensing element to dimensions of approximately $1 \mathrm{~cm}^{3}$ and the surface (tangential) was covered by a thin layer of gold.

The results are mean values between the regions near the medulla, intermediate and near the exchange. 


\section{RESULTS}

\section{Anatomical description of the log}

The main differences between genotypes are inserted in Table 2 and in the following descriptions.

Table 2. Main characteristics to differentiate the genotypes.

Tabela 2. Principais características para diferenciar os genótipos.

\begin{tabular}{|c|c|c|}
\hline Genotype & Axial Parenchyma & Ray \\
\hline E. urophylla $x$ E. grandis & $\begin{array}{l}\text { Paratracheal Vasocentric / } \\
\text { Apotracheal Diffuse }\end{array}$ & Mixture \\
\hline Eucalyptus urophylla & $\begin{array}{l}\text { Vasicentric Paratracheal, } \\
\text { Lozenge-shaped Aliform / } \\
\text { Diffuse Apotracheal }\end{array}$ & Heterogeneous \\
\hline E. urophylla $\times$ E. camaldulensis & $\begin{array}{c}\text { Paratraquel Vasicentric, } \\
\text { Confluent / Apotracheal Diffuse }\end{array}$ & Homogeneous \\
\hline
\end{tabular}

\section{E. urophylla $x$ E. grandis}

Growth layers: are demarcated by the slight decrease in vessel diameter and density, in addition to the thickening in the fiber wall. short fins.

Axial parenchyma: paratraqueal vasocentric and diffracted apotracheal, rare, lozenge-shaped aliform of

Vases: predominantly solitary with proximity between them, however they do not share the same wall. Diagonal arrangement in relation to the radius and diffuse porosity. Average vessel diameter of $128.5 \mu \mathrm{m}$ and frequency of 11 vessels $/ \mathrm{mm}^{2}$. Simple perforation plate, intervascular, alternate and areolated, minute to small, pits; presence of vasicentric tracheids.

Fibres: libriformes, average length of $879.28 \mu \mathrm{m}$ and wall thickness of $4.09 \mu \mathrm{m}$.

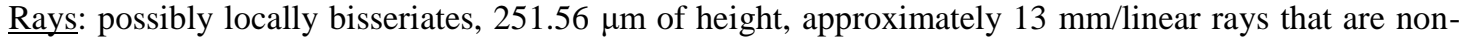
stratified, heterogeneous, formed by procumbent cells in the body and square at the margin, radiovascular pits with apparently simple reduced areolas (Figure 1).

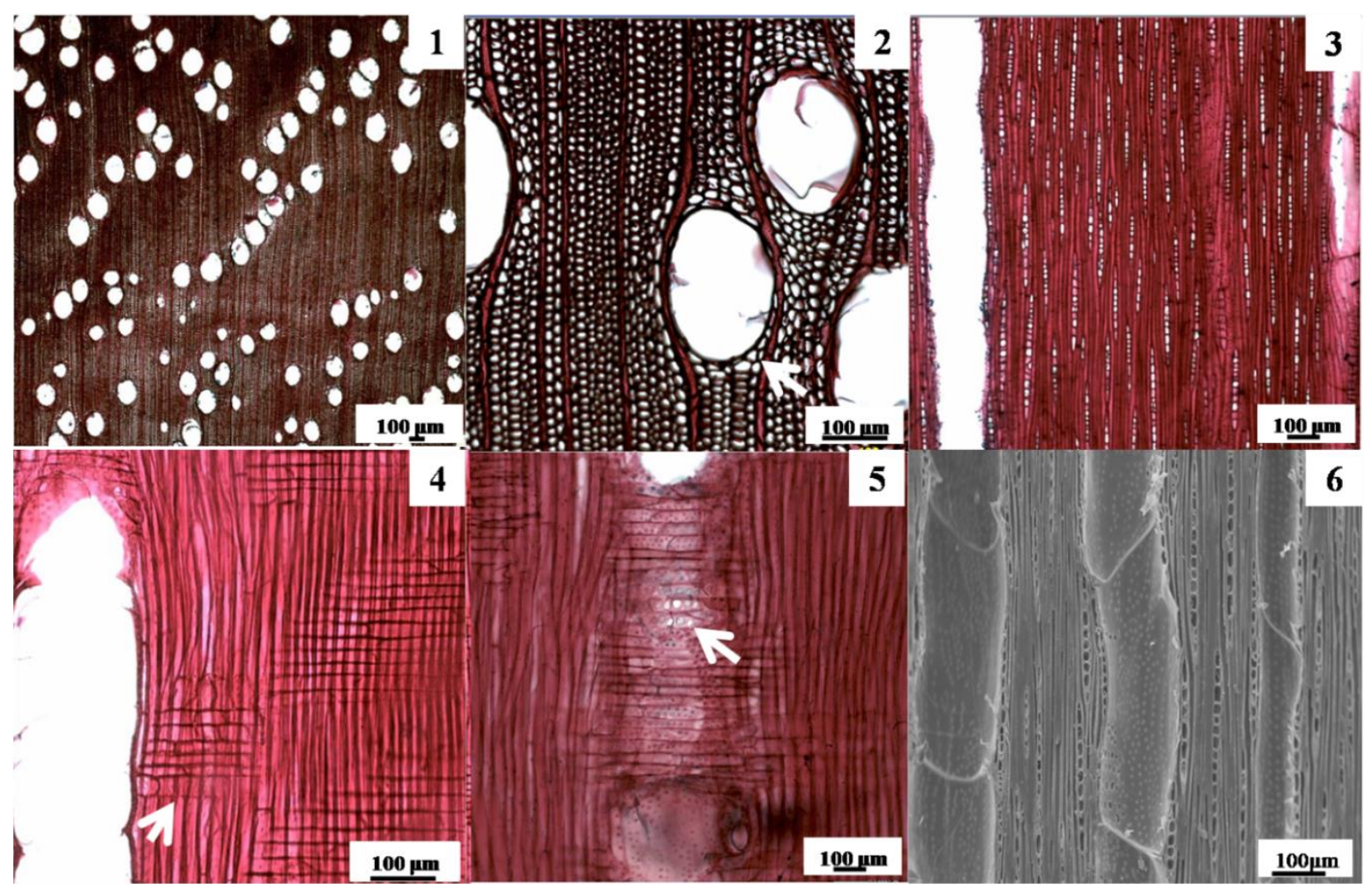

FLORESTA, Curitiba, PR, v. 49, n. 2, p. 297-304, abr/jun 2019. 
Figure 1. Eucalyptus urophylla x Eucalyptus urophylla - Growth strata (1), axial paratracheal parenchyma vasicentric (arrow) (2), non-stratified rays (3), morphology of the cells that make up the rays, presence of square cells in the margin (arrow) (4), radio-vascular spikes (arrow) (5) and intervessel pits (6).

Figura 1. Eucalyptus grandis x Eucalyptus urophylla - Camadas de crescimento (1), parênquima axial paratraqueal vasicêntrico (seta) (2), raios não estratificados (3), morfologia das células que compõe os raios, presença de células quadradas na margem (seta) (4), pontoações radio-vasculares (seta) (5) e pontoações intervasculares (6)

\section{Eucalyptus urophylla}

Growth layer: demarcated by thickening the fiber wall.

Axial parenchyma: paratraqueal vasocentric, lozenge-shaped aliform and diffracted apotracheal.

Vessels:predominantly solitary with proximity between them, however they do not share the same wall, diagonal arrangement in relation to the ray and diffuse porosity, average diameter of the vessel of $109.6 \mu \mathrm{m}$ and frequency of 14 vessels $/ \mathrm{mm}^{2}$. Simple perforation plate, intervascular, alternate and areolated, minute to small, pits; presence of vasicentric tracheids.

Fibres: libriformes, average length of $976.71 \mu \mathrm{m}$ and wall thickness of $4.19 \mu \mathrm{m}$.

Rays: unisseriates, eventually locally bisseriates, $257.11 \mu \mathrm{m}$ of height, approximately $12 \mathrm{~mm} /$ linear rays that are non-stratified, heterogeneous, formed by procumbent square cells in the body, presence of square cells localized in the middle or at the margin, radiovascular pits with apparently simple reduced areolas (Figure 1).

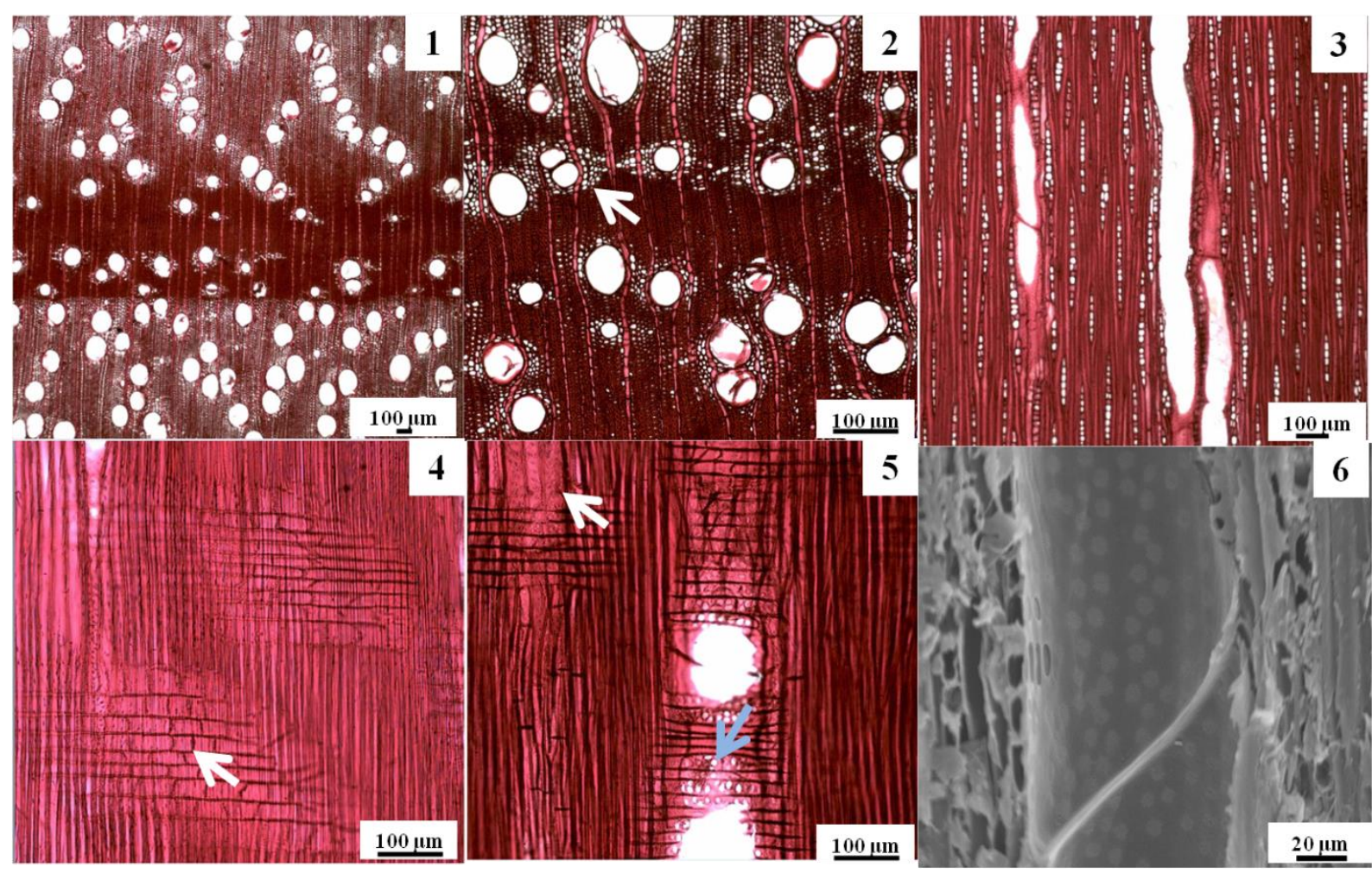

Figure 2. Eucalyptus urophylla - Growth strata (1), lozenge-shaped aliform axial paratracheal parenchyma (arrow) (2), non-stratified rays (3), morphology of the cells that form the rays, presence of square cells in the margin (arrow) (4), radio-vascular, apparently simple, pits (blue arrow), vasicentric tracheids (white arrow) (5) and intervascular pits (6).

Figura 2. Eucalyptus urophylla - Camadas de crescimento (1), parênquima axial paratraqueal vasicêntrico (seta) (2), raios não estratificados (3), morfologia das células que compõe os raios, presença de células quadradas na margem (seta) (4), pontoações radio-vasculares (seta) (5) e pontoações intervasculares (6)

\section{E. urophylla $\mathrm{x}$ E. camaldulensis}

Growth layer: demarcated by decrease in vessel density and diameter. 
Axial parenchyma: paratraqueal vasocentric, rare, lozenge-shaped aliform, there is formation of short confluences and presence of diffuse.

Vessels: predominantly solitary with proximity between them, however they do not share the same wall, diagonal arrangement in relation to the ray and diffuse porosity, average diameter of the vessel of $112.29 \mu \mathrm{m}$ and frequency of 15 vessels $/ \mathrm{mm}^{2}$. Simple perforation plate, intervascular, alternate and areolated, minute to small, pits; presence of vasicentric tracheids.

Fibres: libriforms, average length of $879.39 \mu \mathrm{m}$ and wall thickness of $3.29 \mu \mathrm{m}$.

Rays: possibly locally bisseriates, $251.56 \mu \mathrm{m}$ of height, approximately $13 \mathrm{~mm} /$ linear rays that are nonstratified, heterogeneous, formed by procumbent cells in the body and square at the margin, radiovascular pits with apparently simple reduced areolas (Figure 1) .



Figure 3. Eucalyptus urophylla x Eucalyptus carnadulensis - Growth strata (1), axial vasicentric paratracheal parenchyma (arrow) (2), non-stratified rays (3), morphology of the cells that form the rays, vasentric tracheids (arrow) (4), apparently simple radio-vascular pits (arrow) (5) and intervascular pits (6).

Figura 3. Eucalyptus urophyllax Eucalyptus carnaldulensis - Camadas de crescimento (1), parênquima axial paratraqueal vasicêntrico (seta) (2), raios não estratificados (3), morfologia das células que compõe os raios, presença de células quadradas na margem (seta) (4), pontoações radio-vasculares (seta) (5) e pontoações intervasculares (6)

\section{DISCUSSION}

The study emphasized the differences in the qualitative characteristics, since quantitative characteristics such as fiber length, wall thickness, height and width of ray and vessel diameter and density are influenced by the climatic changes.

The main differences between the studied genotypes were rays and axial parenchyma, Pirralho et al. (2014), studying nine species of Eucalyptus, also noted that most of the anatomical differences in the species of the genus are related to the rays and axial parenchyma. 
The genotypes of Eucalyptus studied in this work are very similar between each other, AngyalossyAlfonso (1987) also observed this homogeneity when studying 21 species of the genus. However, it is possible to differentiate them because they have distinct qualitative characteristics inherited from the species. Thus, it is possible to affirm that there are differences in the anatomical constitution that allows to distinguish the evaluated genotypes even though they are similar to each other.

In all species it was possible to notice the presence of vessels in diagonal arrangement, predominantly solitary and vasicentric tracheids, common characteristics to the species of Eucalyptus reported in several works (ANGYALOSSY-ALFONSO, 1987; ALZATE, 2009; BRISOLA AND DEMARCO, 2011) .

The rays of the studied genotypes are uniseriate, locally bisseriate, as observed in the studies of Alzate (2009), Brisola and Demarco (2011). Regarding the composition of the rays, Alzate (2009), analyzing clones of Eucalyptus grandis x Eucalyptus urophyla, did not notice the presence of square cells, considering the rays as homogeneous formed exclusively by procumbent cells.

Describing the secondary xylem of Eucalyptus benthamii Baldin et al. (1989) observed the presence of square cells, corroborating the one affirmed by Record and Hess (1949) that for the set of species of the family Myrtaceae there is the predominance of heterogenous rays.

Brisola and Demarco (2011) also observed vasocentric paratracheal axial parenchyma in Eucalyptus urophylla and eventually aliform in the hybrid Eucalyptus urophylla x Eucalyptus grandis.

It was observed that Eucalyptus urophylla and Eucalyptus urophylla $x$ Eucalyptus grandis, as well as paratracheal parenchyma, also presented diffuse apotracheal parenchyma with little contrast in the transversal plane, constituting a novelty.

Evangelista et al. (2010), when studying clones of Eucalyptus urophylla and Eucalyptus camaldulensis described the presence of confluent and vasicentric paratracheal parenchyma, respectively.

The Eucalyptus urophylla x Eucalyptus camaldulensis hybrid described in this study has a vasicentric axial parenchyma and a rare presence of a lozenge-shaped aliform, presenting a similarity to genotype Eucalyptus urophylla, also described in this paper and reported by Brisola and Demarco (2011). Thus, it is possible that these characteristics of Eucalyptus urophylla are dominant in relation to Eucalyptus camaldulensis, due to the presence of the aliform parenchyma with an elongated extension in both E. urophylla and in the hybrid E. urophylla $\mathrm{x}$ E. camaldulensis.

Libriforms fibres and non-septades were found in the genotypes and are reported in studies with species of the genus (Brisola e Demarco, 2011; Pirralho et al., 2014; Baldin et al., 2017), being the quantitative part of this anatomical character one of the principles considered to the industries of the forest sector.

\section{CONCLUSION}

- It is possible to distinguish the genotypes of Eucalyptus by the characteristics of the axial and radial parenchyma cells;

- Eucalyptus urophylla $x$ E. grandis and Eucalyptus urophylla presented heterogeneous rays with the presence of procumbent and square cells, Eucalyptus urophylla $x$ E. camaldulensis presented a homogeneous ray, composed only of square cells;

- Eucalyptus urophylla $x$ E. grandis presented vasicentric axial parenchyma and diffuse apotracheal, Eucalyptus urophylla, vasocentric, aliform and apotracheal diffuse, and Eucalyptus urophylla $x$ E. camaldulensis confluent vasicentric and diffuse apotraqueal.

- The diagonal arrangement of vessels and the presence of vasicentric tracheids were observed in all genotypes.

\section{REFERENCES}

ALVES, ICN; GOMIDE, JL; COLODETTE, JL SILVA, HD Technological characterization of Eucalyptus benthamii wood for the production of Kraft cellulose. Forest Science, Santa Maria, v. 21, n. 1, p. 167-174, 2011.

ALZATE, SBA Anatomical structure of the wood of Eucalyptus clones. Applied Research Review, Medelín, v.5, n.1, p.1-14, 2009.

ANGYALOSSY-ALFONSO, V. Anatomical characterization of the log and bark of the main species of Eucalyptus L'Hérit. cultivated in Brazil. Thesis (Doctorate in Biological Sciences) - University of São Paulo, São Paulo, 1987. 
BALDIN, T.; MARCHIORI, JNC; TALGATTI, M. Wood anatomy of Eucalyptus benthamii Maiden \& Cambage, a promising species for the cellulose sector in southern Brazil. Balduinia, n. 59, p.10-18, 2017.

BRISOLA, SH; DEMARCO, D. Anatomical analysis of the stem of Eucalyptus grandis, E. urophylla and E. grandis $x$ urophylla: timber development and its importance for industry. Scientia Florestalis, Piracicaba, v. 39 , n. 91, p. 317-330, 2011.

CARLQUIST, S. Caryophyllales: a key group for understanding wood anatomy character states and their evolution. Botanical Journal of the Linnean Society, v. 164, n. 4, p. 342-393, 2010.

DIAS JÚNIOR, AFC; ANDRADE, AMD; OLIVEIRA, ED; LANA, AQ; BRITO, JO Quality of Eucalyptus Wood Grown in Rio de Janeiro State for Bioenergy. Forest and Environment, v. 23, n. 3, p. 435-442, 2016.

EVANGELISTA, WV; SILVA, JC; VALLE, MLA; XAVIER, B. Quantitative anatomical characterization of wood from clones of Eucalyptus camaldulensis Dehnh. and Eucalyptus urophylla ST Blake. Scientia Florestalis, Piracicaba, v. 38, n. 86, p. 273-284, 2010.

IAWA COMMITTEE. International Association of Wood Anatomists. List of microscopic features for hardwood identification. IAWA Bulletin, v. 10, p.220-332, 1989.

RAPASSI, RMA; TARSITANO, MAA; PEREIRA, JCR; MORAES E ARAUJO, CA Eucalyptus culture in the Suzanápolis region, State of São Paulo: Economic analysis. Economic Information, v. 38, p. 7-13, 2008.

RECORD, SJ; HESS RW Timbers of the New World. New Haven Yale Univ. Press, 1949.

BRAT, M; FLORES, D.; SOUSA, VB; QUILHÓ, T .; KNAPIC, S .; PEREIRA, H. Evaluation on paper making potential of nine Eucalyptus species based on wood anatomical features. Industrial Crops and Products, p. $327-$ 334, 2014.

PRINSEN, P.; GUTIÉRREZ, A .; RENCORET, J .; NIETO, L .; JIMÉNEZ-BARBERO, J .; BURNET, A; PETITCONIL, M .; COLODETTE, JL; MARTÍNEZ, Á. T .; RIO, J.C. Morphological characteristics and composition of lipophilic extracts and lignin in Brazilian woods from different eucalypt hybrids. Industrial Crops and Products, v. 36, n. 1, p. 572-583, 2012. 
FLORESTA, Curitiba, PR, v. 49, n. 2, p. 297-304, abr/jun 2019 Lopes. O. P. et.al. 